\title{
Do climate variables and human density affect Achatina fulica (Bowditch) (Gastropoda: Pulmonata) shell length, total weight and condition factor?
}

\author{
Albuquerque, FS. ${ }^{\mathrm{a} *}$, Peso-Aguiar, MC. ${ }^{\mathrm{b}}$, Assunção-Albuquerque, MJT. ${ }^{\mathrm{a} *}$ and Gálvez, L. $^{\mathrm{a} *}$ \\ ${ }^{a}$ Universidad Alcalá de Henares, \\ Edificio de Ciencias, Ctra. Madrid-Barcelona, Km 33,6, 28871, Alcalá de Henares, Madrid, Spain \\ ${ }^{b}$ Universidade Federal da Bahia - UFBA, \\ Rua Barão de Geremoabo, 147, Campus de Ondina, CEP 40170-290, Salvador, BA, Brazil \\ *e-mail: fabio.suzart@alu.uah.es, mpeso@ufba.br, mariajose.teixeira@alu.uah.es, lucia.galvez@uah.es \\ Received November 1, 2007 - Accepted February 12, 2008 - Distributed August 31, 2009
}

(With 5 figures)

\begin{abstract}
The length-weight relationship and condition factor have been broadly investigated in snails to obtain the index of physical condition of populations and evaluate habitat quality. Herein, our goal was to describe the best predictors that explain Achatina fulica biometrical parameters and well being in a recently introduced population. From November 2001 to November 2002, monthly snail samples were collected in Lauro de Freitas City, Bahia, Brazil. Shell length and total weight were measured in the laboratory and the potential curve and condition factor were calculated. Five environmental variables were considered: temperature range, mean temperature, humidity, precipitation and human density. Multiple regressions were used to generate models including multiple predictors, via model selection approach, and then ranked with AIC criteria. Partial regressions were used to obtain the separated coefficients of determination of climate and human density models. A total of 1.460 individuals were collected, presenting a shell length range between 4.8 to $102.5 \mathrm{~mm}$ (mean: $42.18 \mathrm{~mm}$ ). The relationship between total length and total weight revealed that Achatina fulica presented a negative allometric growth. Simple regression indicated that humidity has a significant influence on A. fulica total length and weight. Temperature range was the main variable that influenced the condition factor. Multiple regressions showed that climatic and human variables explain a small proportion of the variance in shell length and total weight, but may explain up to $55.7 \%$ of the condition factor variance. Consequently, we believe that the well being and biometric parameters of A. fulica can be influenced by climatic and human density factors.
\end{abstract}

Keywords: Achatina fulica, alien species, gastropoda, condition factor, invasiveness species.

\section{Variáveis ambientais e humanas afetam o comprimento da concha, peso total e fator de condição de Achatina fulica (Gastropoda: Pulmonata)?}

\begin{abstract}
Resumo
A relação peso comprimento e o fator de condição têm sido bastante explorados em pesquisas envolvendo caracóis para obter o índice de condição física em populações e avaliar a condição do habitat. Neste trabalho, nosso objetivo foi descrever que variáveis influenciam os parâmteros biométricos e o bem estar de Achatina fulica em uma recente introdução. De novembro de 2001 a novembro de 2002, amostras mensais desses caracóis foram coletadas na cidade de Lauro de Freitas (Bahia), Brasil. Em seguida, os caracóis foram acondicionados em laboratório e foram obtidos o tamanho da concha e o seu peso. A partir desses dados a curva potencial e o fator de condição foram calculados. Cinco variáveis ambientais foram consideradas: amplitude de temperatura, temperatura média, humidade, precipitação e densidade humana. Regressões múltiplas foram usadas para gerar modelos preditivos através do critério de seleção e logo foram ordenados utilizando o critério de Akaíke. Regressões parciais foram usadas para obter os coeficientes de determinação do clima e fatores humanos. Um total de 1460 indivíduos foram coletados, apresentando uma amplitude de crescimento de concha entre 4,9 a 102,5 mm (média 42,18 mm). A relação entre o crescimento total e o peso revelou que A. fulica apresentou um crescimento alométrico negativo. Regressões simples indicaram que a umidade teve uma influencia significativa sobre o tamanho total e o peso. A amplitude de temperatura foi a variável que mais influenciou o fator de condição. Os modelos de regressão múltipla indicaram que os fatores climáticos e
\end{abstract}


humanos explicaram uma pequena porção da variança, no entanto explicou 55,8\% da variância do fator de condição. Consequentemente, acreditamos que o bem estar e os parâmetros biométricos de A. Fulica podem ser influenciados por fatores climáticos e humanos.

Palavras-chave: Achatinha fulica, espécies exóticas, Gastropoda, fator de condição, espécies invasoras.

\section{Introduction}

Many studies have been carried out to investigate Achatina fulica dispersal, distribution and biology around the world (Bequaert, 1950; Mead, 1961; Godan, 1983; Takeda and Ozaki, 1986; Koyano et al., 1989; Mead, 1982; Tomiyama, 1992; 1993; 1994; Shah, 1995; Panja, 1995; Simberloff, 1995; Cowie, 1998; Graeff-Teixeira et al., 1998). However, the effects of climatic factors on the biology of this species are still unknown.

Understanding the factors that govern A. fulica body size, total weight and condition factor could be an important pest management tool where there is a scarcity of data. This snail may reach high abundances and cause important economic losses under favourable environmental conditions. Therefore, climate is expected to be a strong predictor of $A$. fulica density and biomass (Rauth and Barker, 2002). Strong climatic changes may induce hibernation, mainly if temperature and humidity reach low values (Mead, 1961; Raut and Ghose, 1984). The aestivation stage may promote physiological changes in A. fulica and affect this snail's development (Vinci et al., 1998).

The condition factor expresses the relationship between weight and length (Le Cren, 1951; Weatherley and Gill, 1987). This factor reflects changes in the animal's physiology, especially during aestivation, and has also been broadly used to estimate mean weight from a known length and to calculate the index of physical condition of populations (Beyer, 1987; Vinci, 1998; Bolger and Connoly, 1989; Albertoni et al., 2003). Furthermore, the condition factor is very useful to evaluate habitat quality and may contribute to assess population welfare (Le Cren, 1965; Ricker, 1975; Bolger and Connoly, 1989).

However, there are very few investigations regarding the factors that influence $A$. fulica's growth and development. In this study, we addressed two questions: 1) what is the influence of climatic variables and human influence on A. fulica 's shell length and weight ? 2) Do climatic variables and human density affect $A$. fulica 's well being?

\section{Material and Methods}

This study was carried out at Lauro de Freitas City (12 ${ }^{\circ} 54^{\prime} \mathrm{S}$ and $38^{\circ} 19^{\prime} \mathrm{W}$ ), which belongs to the Salvador Metropolitan Area, Bahia state (NE), Brazil (Figure 1). Lauro de Freitas covers an area of $60 \mathrm{Km}^{2}$, and has a population of 113,543 inhabitants $(1,892.4$ hab/ $\mathrm{km}^{2}$ ). These data were obtained from the Brazilian Institute of Geography and Statistic and are available at http://www.ibge.gov.br/cidadesat/xtras/perfil. php? codmun $=292740 \& \mathrm{r}=2$. Annual average temperature is $27^{\circ} \mathrm{C}$ and total annual precipitation is about $2,000 \mathrm{~mm}$ (Table 1).

A. fulica was carefully searched for from September 2001 to November 2002, at different periods, including rainy days each month, and a minimum of 50 snails were randomly collected within the study area. Sampling took place during day and night times (Molgaard, 1986; Iglesias and Castillejo, 1998; Hatziioannou et al., 1994). Snails were transported to the laboratory and measurements of total length (Lt), length from the top of the shell to the aperture, and total weight $(\mathrm{Wt})$ were taken. Measurement precision was $0.01 \mathrm{~mm}$ for length and $0.0001 \mathrm{~g}$ for weight. With these data, the relationships between length and weight and condition factor were determined using the equations: $\mathrm{W}_{\mathrm{t}}=\mathrm{aL}_{\mathrm{t}}^{\mathrm{b}}\left(\mathrm{W}_{\mathrm{t}}=\right.$ total weight, $\mathrm{L}_{\mathrm{t}}=$ total length, $\mathrm{a}$ and $\mathrm{b}$ are growth parameters) (Weatherley, 1972; Weatherley and Gill, 1987); and the condition factor $(\mathrm{K})$ was calculated following the equation $\mathrm{K}=\mathrm{W}_{\mathrm{t}} / \mathrm{L}_{\mathrm{t}}^{\mathrm{b}}$. Depending on the value of the allometric coefficient, the growth was considered isometric $(b=3)$, positive allometric $(b>3)$ or negative allometric (b < 3) (Stergiou, 1993).

Five environmental variables were included in the models: temperature range, mean temperature, humidity, precipitation and human density. These variables have been shown to be the best predictors of snail biometric parameters (Takeuchi, 1991; Rauth and Barker, 2002). Environmental data were available from meteorological stations located in the Lauro de Freitas area, at the

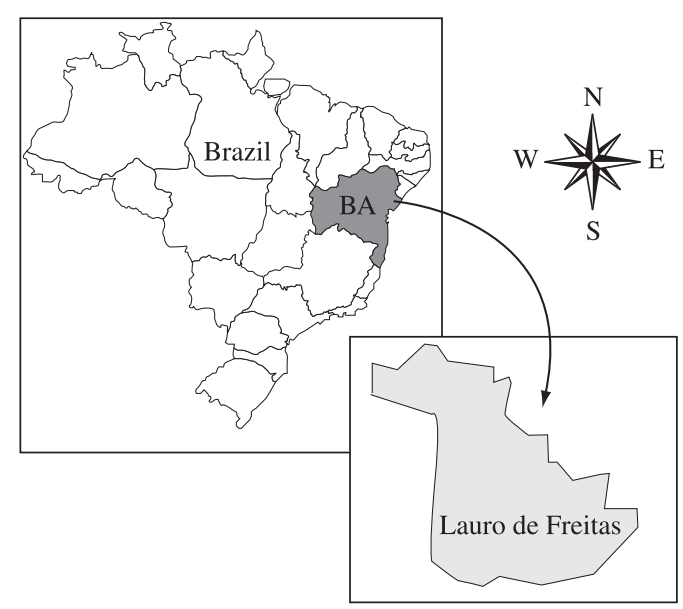

Figure 1. Localization of Lauro de Freitas city in Brazil. 
National Meteorology Institute (INMET - www.inmet. gov.br) and are displayed in Table 1. Human density data were obtained from the Socioeconomic Data and applications centre (http://sedac.ciesin.columbia.edu) and from Lauro de Freitas City Hall.

At first, simple regressions were performed to test the relationship between snail biometric parameters and predictor variables. Then, multiple regressions were carried out to obtain the best model supported by the data using the model selection approach criteria based on information theory, widely used to generate environmental models with multiple predictors (see in Burnham and Anderson, 2002). This criterion may be useful to identify a single model from a particular hypothesis or infer the best solution from a set of competitive models (Johnson and Omland, 2004). However, there are some variables that are highly correlated and their effects on biometric parameters would be hard to differentiate (Draper and Smith, 1981; Francis and Currie, 1988; Diniz-Filho et al., 2003). Thus, a correlation matrix of environmental variables was used to test the level of multicollineaty in the data set (Table 2). Variables with correlation coefficients higher than 0.65 were not included in the same model. Once the models were obtained, the Akaike Criterion (AIC) was used to rank competing models (Johnson and Omland, 2004).
Even so, the possible colinearity between climate variables and human attributes may make difficult the interpretation of multiple-regressions models. Thus, we used partial regressions analyses to partition the variance explained by climate variables and human attributes. All statistical analyses were carried out using Statistica (StatSoft, Inc., 2003) and Spatial Analyses in Macroecology (SAM) (Rangel et al., 2006).

\section{Results}

1.460 individuals with length ranging between 4.8 and $102.5 \mathrm{~mm}$ and a mean length of $42.18 \mathrm{~mm}$ were collected. It was noted that most individuals fell between 32.9 and $39.5 \mathrm{~mm}$ (19\% of the sample) followed by $18.3 \%$ between 26.3 and $32.9 \mathrm{~mm}$. Individuals of length $<10.00 \mathrm{~mm}$ were present throughout the year but showed a low frequency $(4.52 \%)$ (Figure 2).

The relationship between total length and total weight reveals that Achatina fulica presented a negative allometric growth throughout the year, with $\mathrm{b}=2.60$ and $\mathrm{R}^{2}=0.93$. The allometric equation for this snail in this year was $\mathrm{W}_{\mathrm{t}}=0.0006 \mathrm{Lt}^{2.60}$ (Figure 3 ). The condition factor showed little variation throughout the year, presenting a high peak in autumn. Similar values were ob-

Table 1. Monthly environmental variable values in Lauro de Freitas City.

\begin{tabular}{lcccc}
\hline $\begin{array}{c}\text { Variable } \\
(\mathbf{m o n t h s})\end{array}$ & $\begin{array}{c}\text { Temperature } \\
\text { range }\left({ }^{\circ} \mathbf{C}\right)\end{array}$ & $\begin{array}{c}\text { Mean } \\
\text { temperature }\left({ }^{\circ} \mathbf{C}\right)\end{array}$ & $\begin{array}{c}\text { Humidity } \\
(\mathbf{\%})\end{array}$ & $\begin{array}{c}\text { Precipitation } \\
(\mathbf{m m})\end{array}$ \\
\hline November & 4 & 24.3 & 90 & 112.1 \\
December & 2.7 & 26.9 & 65 & 252.4 \\
January & 9.8 & 27.1 & 63 & 103.1 \\
February & 10 & 26.9 & 82 & 102.1 \\
March & 12 & 26.5 & 76 & 69.3 \\
April & 11.1 & 26.3 & 85 & 351.6 \\
May & 4 & 24.6 & 83 & 209.2 \\
June & 5 & 24 & 86 & 254.8 \\
July & 5 & 24 & 81 & 162.8 \\
August & 7 & 24.3 & 82 & 257.8 \\
September & 8 & 25.8 & 76 & 16 \\
October & 9 & 26.5 & 78 & 25.2 \\
November & 5 & 26.9 & 75 & 30.5 \\
\hline
\end{tabular}

Table 2. Correlation matrix for environmental variables.

\begin{tabular}{lccccc}
\hline \multicolumn{1}{c}{ Variable } & Temp range & $\begin{array}{c}\text { Mean } \\
\text { temperature }\end{array}$ & Humidity & Precipitation & $\begin{array}{c}\text { Human } \\
\text { Density }\end{array}$ \\
\hline Temperature range & 1.00 & - & - & - & - \\
Mean temperature & 0.49 & 1.00 & - & - & - \\
Humidity & -0.09 & -0.68 & 1.00 & - & - \\
Precipitation & -0.19 & -0.35 & 0.25 & 1.00 & - \\
Human density & 0.18 & -0.18 & -0.02 & 0.19 & 1.00 \\
\hline
\end{tabular}


served in the winter and low values were found in spring (Figure 4).

Simple regressions showed that humidity had a significant influence on A. fulica total length and weight (Table 3 ). Temperature range was the only significant variable that influenced the condition factor. In total, 128 models were generated from the biometric values, the climatic variables and human density. Humidity was present in almost all best ranked models for shell length and total weight (Table 4). Precipitation was the second most important variable explaining shell length of A. fulica and temperature was another important variable that influenced total weight.

However the explanatory power of these models was not high. The model that best explained shell length only explained $27.5 \%$. The second model, composed of hu-

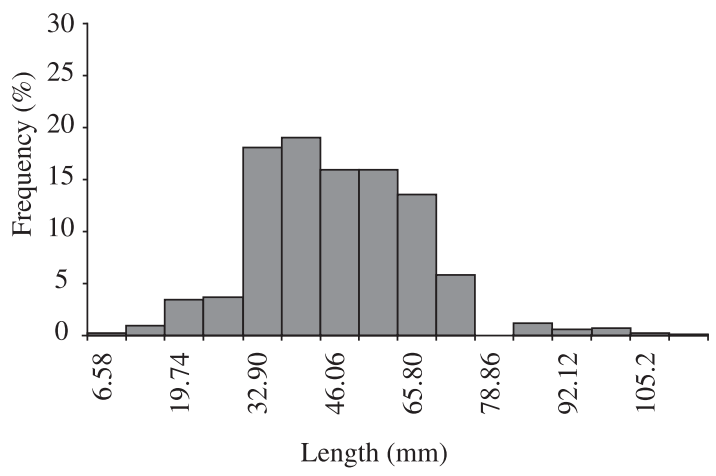

Figure 2. Frequency of the total shell length of Achatina fulica in Lauro de Freitas City. Classes were calculated by Sturge's formula (1978) and presented a range of $6.58 \mathrm{~mm}$.

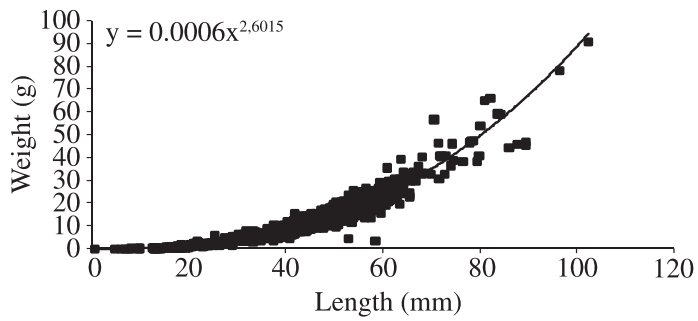

Figure 3. Allometric relationship between total shell length $(\mathrm{mm})$ and total weight $(\mathrm{g})$. midity and precipitation, also explained a small proportion, but slightly higher than the first model (Table 4). All predictive models for weight had low explanatory power: the first model ranked by AIC, comprised by humidity and temperature range, explained only $38.7 \%$ of the variance. The second model only included humidity, and explained $32.5 \%$ of the variance in weight. Condition factor was best predicted by a model that included temperature range and human density as the main explanation for welfare variance, $55.6 \%$ (Table 4).

The partial correlation showed that the isolated effect of human density was not dissociated for shell length and total weight, and a large overlap between this variable and climatic factor was noted. The same result was observed for the condition factor but with only a small isolated influence of human density (Figure 5).

\section{Discussion}

Our results showed that environmental variables and human density may affect Achatina fulica shell length, total weight and condition factor. This is illustrated by our results that also answer basic questions proposed in the introduction. Although there are several hypotheses to explain the growth of A. fulica, shell length and body weight are commonly used to investigate mollusc growth, particularly in bivalves (Kornobis, 1977; Walz, 1978; Haag and Garton, 1992; Smith et al., 1992). In terms of shell length, previous studies estimated that the maximum shell length of Achatina fulica may reach $30 \mathrm{~cm}$ (Vinci et al., 1998). Others report low values such as $10 \mathrm{~cm}$ (Godan, 1983; Raut and Ghara, 1990). In ac-

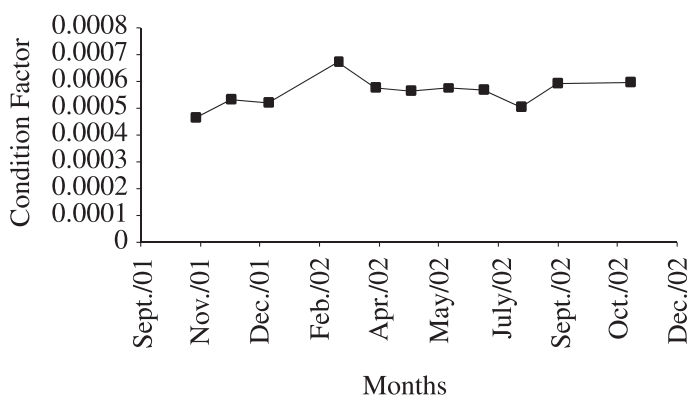

Figure 4. Condition factor of Achatina fulica in Lauro de Freitas City, from November 2001 to December 2002.

Table 3. Simple regressions of predictors against Achatina fulica total length (mm), total weight (g) and the condition factor.

\begin{tabular}{|c|c|c|c|c|c|c|}
\hline \multirow[t]{2}{*}{ Variables } & \multicolumn{2}{|c|}{ Total length (mm) } & \multicolumn{2}{|c|}{ Total weight (g) } & \multicolumn{2}{|c|}{ Condition factor } \\
\hline & $\mathbf{r}$ & Probability & $\mathbf{r}$ & Probability & $\mathbf{r}$ & Probability \\
\hline Temperature range & 0.111 & $<0.01$ & 0.189 & $<0.1$ & 0.572 & $<0.0001$ \\
\hline Mean temperature & 0.278 & $>0.1$ & 0.258 & $>0.1$ & 0.107 & $>0.1$ \\
\hline Humidity & 0.552 & $<0.01$ & 0.573 & $<0.01$ & 0.270 & $>0.1$ \\
\hline Precipitation & 0.445 & $<0.01$ & 0.347 & $<0.01$ & 0.038 & $>0.1$ \\
\hline Human density & 0.132 & $>0.1$ & 0 & $>0.1$ & 0.572 & $>0.1$ \\
\hline
\end{tabular}


Table 4. Multiple-regression results for Achatina fulica abundance. Models are ranked in each case by AIC from best to the worst model.

\begin{tabular}{|c|c|c|c|c|c|c|c|}
\hline \multirow[t]{2}{*}{ Models } & \multicolumn{5}{|c|}{ Variables } & \multirow[t]{2}{*}{ AIC } & \multirow[t]{2}{*}{$\mathbf{r}^{2}$} \\
\hline & $\begin{array}{c}\text { Temperature } \\
\text { range }\end{array}$ & $\begin{array}{c}\text { Mean } \\
\text { temperature }\end{array}$ & Humidity & Precipitation & $\begin{array}{l}\text { Human } \\
\text { density }\end{array}$ & & \\
\hline \multicolumn{8}{|l|}{ Total length } \\
\hline Model 1 & - & - & 0.525 & - & - & 108,645 & 0.275 \\
\hline Model 2 & - & - & 0.481 & 0.333 & - & 109,121 & 0.380 \\
\hline Model 3 & - & - & - & 0.488 & - & 109,482 & 0.190 \\
\hline Model 4 & - & - & 0.523 & - & -0.120 & 110,328 & 0.290 \\
\hline \multicolumn{8}{|l|}{ Total weight } \\
\hline Model 1 & 0.395 & - & 0.594 & - & - & 78,939 & 0.387 \\
\hline Model 2 & - & - & 0.594 & - & - & 79,121 & 0.329 \\
\hline Model 3 & - & - & 0.519 & 0.216 & - & 80,200 & 0.373 \\
\hline Model 4 & - & 0.244 & 0.731 & - & - & 80,542 & 0.361 \\
\hline \multicolumn{8}{|c|}{ Condition factor } \\
\hline Model 1 & 0.514 & - & - & - & 0.483 & $-182,494$ & 0.557 \\
\hline Model 2 & - & 0.659 & 0.585 & - & 0.636 & $-182,223$ & 0.576 \\
\hline Model 3 & 0.500 & - & 0.137 & - & 0.452 & $-181,891$ & 0.575 \\
\hline Model 4 & - & - & 0.206 & -0.180 & 0.506 & $-181,814$ & 0.362 \\
\hline
\end{tabular}

Total Weight $\left(\mathrm{W}_{\mathrm{t}}\right)$

\begin{tabular}{l}
$|c| c \mid d$ \\
\hline \multicolumn{1}{|c|}{ Climate } \\
$\mathrm{a}=0.532$ \\
$\mathrm{~b}=0$ \\
$\mathrm{c}=0$ \\
$\mathrm{~d}=0.478$
\end{tabular}

Total Lenght $\left(\mathrm{L}_{\mathrm{t}}\right)$

\begin{tabular}{|c|c|}
$\mathrm{a}$ & $\mathrm{d}$ \\
\hline Climate & \\
\hline
\end{tabular}

$\mathrm{a}=0.275$

$\mathrm{b}=0$

$\mathrm{c}=0$

$\mathrm{d}=0.725$

Condition Factor $(\mathrm{K})$

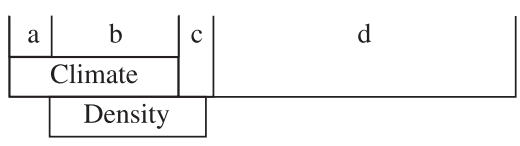

$$
\begin{aligned}
& a=0.034 \\
& b=0.273 \\
& c=0.025 \\
& d=0.668
\end{aligned}
$$

Figure 5. Partial Regression analyses for the best model describing Achatina fulica Total weight, total length and condition factor. Portioning the independent contributions of a) pure climatic variables, c) human density, b) the overlap between climate and human density and d) represents the proportion of variation in richness not explained by either factor. cordance with Godan (1983) and Raut and Ghara (1990), measurements of A. fulica body size in Lauro de Freitas city reach a maximum shell length of $10 \mathrm{~cm}$.

Two other factors should be highlighted here regarding to shell length. First, the establishment of Achatina fulica in new areas takes place in three stages: exponential, known as a long phase with vigorous individuals, stable, with a prevalence of a variable young and adult shell size, and the decline phase, where there is a prevalence of young individuals (Mead, 1982; Pointer and Blanc, 1985). According to our results, the A. fulica population in Lauro de Freitas City is currently at the second phase, presenting a great variety of young and adult snails.

Second, studies taking into account allometric growth suggest that a negative growth may result in a rounded shell or body shape and may also influence the maximum shell length of a population (Godan, 1983; Vinci et al., 1988; Raut and Ghara, 1990; Abertoni et al., 2003). Our results indicated that A. fulica presented a negative allometric growth and this may affect its maximum shell length and consequently their total weight.

In addition, environmental factors may affect the biometry of this snail (Mead, 1961). Achatina fulica is a nocturnal snail and moisture dependent, being more active in high humidity conditions (Raut and Ghose, 2002). We noted that humidity was the main factor that influenced A. fulica shell size and total weight. Takeda and Osaki (1986) found that A. fulica becomes active when humidity rises over $50 \%$ and also reported that mean temperature and temperature range affected A. fulica body weight. Besides, long dry periods and severe temperature changes may promote the aestivation of this snail (Suzuki and Yasuda, 1983; Takeuchi et al., 1991). 
As the snails fall into the aestivation state a very important physiological change occurs, resulting in a reduction of the heart rate and gradual animal dehydration (Raut and Rahman, 1991). This indicates that A. fulica could be highly dependent on the size of the climatically suitable range and also gives support to the hypothesis that humidity can affect the growth of A. fulica. Whatever the strongest explanation for A. fulica growth, our results provide evidence that measures of climate and human density affects the shell length and total weight of Achatina fulica.

Furthermore, the condition factor reflects the snail's welfare and responds to physiological changes, especially during the aestivation stage and periods of low moisture (Vinci et al., 1998; Albertoni et al., 2003). Even though in the study area there were no severe changes in mean temperature and humidity during our study, our results indicated that climatic variables and human density explain great proportions of variance of the condition factor. Also, the simple regression showed that temperature range was the most correlated environmental variable with this index. Therefore, stable climatic conditions are important for the development and well being of this snail.

Although the biometry of Achatina fulica can be influenced by environmental parameters, a very small portion of the variance was explained by these parameters. This indicates that other variables, like topography, edaphic factors and biotic interactions could be important and should be included in future studies involving A. fulica growth. However, we observed that climatic variables and human density explained a significant portion of the condition index variance, so we can conclude that these are the main factors that influence $A$. fulica welfare and can be used in evaluations of habitat quality. Further, predictive models with environmental predictors can be used to assess where species will move in space and time. In sum, future studies with regard to A. fulica development should take into consideration measures of climate and human variables to better understand what factors have a strong effect on A. fulica growth.

\section{References}

ALBERTONI, EF., PALMA-SILVA, C. and ESTEVES, FA., 2003. Overlap of Dietary Niche and Electivity of Three Shrimp Species (Crustacea: Decapoda) in a Tropical Coastal Lagoon (Rio de Janeiro, Brazil). Revista Brasileira de Zoologia, vol. 20, no. 1 , p. 135-140.

BARQUET, JC., 1950. Studies on the achatinidae, a group of African Land Snail. Bulleting of the Museum of Comparative Zoology, vol.105, p. 1-216.

BEYER, JE., 1987. On lenght-weigth relationships. Part I: Computing the mean weight of the fish of a given lenght class. Fishbyte, vol. 5, no. 1, p. 11-13.

BOLGER, T. and CONNOLLY, PL., 1989. Selection of suitable indices for the measurement and analysis of fish condition. Journal of Fish Biology, vol. 34, no. 1, p. 71-182.
BURHAM, KP. and ANDERSON, DR., 2002. Model selection and multimodel inference. New York: Springer.

COWIE, RH., 1998. Patterns of introduction of non-indigenous non-marine snail and slugs in Hawaian Islands. Biodiversity and Conservation, vol. 7, no. 3, p. 349-368.

DINIZ-FILHO, JAF., BINI, LM. and HAWKINS, BA., 2003. Spatial autocorrelation and red herrings in geographical ecology. Global Ecology and Biogeography, vol. 12, no. 1, p. 53-64.

DRAPER, NR. and SMITH, H., 1981. Applied regression analysis. 2 ed. New York: John Wiley. 709 p.

FRANCIS, AP. and CURRIE, DJ., 1998. Global patterns of tree species richness in moist forests: another look. Oikos, vol. 81, no. 2 , p. 598-602.

GODAN, D., 1983. Pests Slugs and Snails. Berlin: SpringerVerlag. $445 \mathrm{p}$.

GRAEFF-TEIXEIRA, C., 1998. Epidemiology of Abdominal Angiostrongylosis in Southern Brasil. Parasitology International, vol. 47, no. 3, p. 23-48.

HAAG, WR. and GARTON, DW., 1992. Synchronous spawning in a recently established population of the zebra mussel, Dreissena polymorpha, in western Lake Erie, USA. Hydrobiologia, vol. 234, no. 3, p. 103-110.

HATZIIOANNOU, H., ELEUTHERIADIS, N. and LAZARIDOUODIM ITRIADOU, M., 1994. Food preferences of dietary overlap by terrestrial snail in Logos area (Edessa, Macedonia, Northern Greece). Journal of Molluscan Studies, vol. 60 , no. 3 , p. $331-341$

IGLESIAS, J. and CASTILLEJO, J., 1998. Field observation on feeding of land snail Helix apersa Muller. Journal of Molluscan Studies, vol. 64, no. 4, p. 411-423.

JOHNSON, JB. and OMLAND, KS., 2004. Model selection in ecology and evolution. Trends in Ecology and Evolution, vol. 19 , no. 2, p. 101-108

KOMOBIS, S., 1977. Ecology of Dreissena polymorpha (Pall.) (Dreissenidae, Bivalvia) in lakes receiving heated water discharges. Polish archives of hydrobiology, vol. 24, no. 4, p. $531-545$.

KOYANO, S., NUMAZAWA, K. and AKEUCHI, K., 1989. Ecology of Giant African Snail in Japan. Plant Protection, vol. 43 , no. 3 , p. 53-56.

LE CREN, E., 1951. The length - weight relation and seasonal cycle in gonad weight and condition in the perch, Perca fluvialitis. Journal of Animal Ecology, vol. 20, no. 2, p. 201-219.

MEAD, AR., 1961. The Giant African Snail: a problem in Economic Malacology. Chicago, U.S.A.: The University Chicago Press

1982. The giant african snail enter the commercial field. Malacologia, vol. 22, p. 489-493.

MOLGARD, P., 1996. Food Plant Preferences by Slugs and Snail: A simple method to evaluate the relative palatability of foods plants. Biochemical Systematic and Ecology, vol. 14, no. 1 , p. 113-121.

PANJA, UK., 1995. Activity pattern in respect to homing of the Giant African Snail, Achatina fulica in laboratory culture. In: Rauth, SK. and Barker, GM. Achatina fulica Bowdich and other achatinidae as a pests in tropicultural agriculture. Molluscs as 
Crop Pest. New Zealand: Ed. By Landscare Research Hamilton. $472 \mathrm{p}$.

POINTIER, JP. and BLANC, C. 1995. Achatina fulica en Polynése Francaise. Répartition, caracterisátion des populations et conséquences de l'introduction de l'escargot predateur Euglandina Rosea en 1982-1983 (Gastropoda - Stylommatophora, Achatinacea). Malakalogische Abhandlungen, vol. 11, no. 1, p. 1-15.

RANGEL, TFLVB., DINIZ-FILHO, JAF. and BINI, LM., 2006. Towards an Integrated Computational Tool for Spatial Analysis in Marcoecology and Biogeography. Global Ecology and Biogeography, vol. 15, no. 4, p.321-327.

RAUT, SG. and GOSHE, KC., 1984. Pestiferous land snails of India. Calcuta: Bani Press. 151 p. Zoological Survey of India № 11.

RAUTH, SK. and GHARA, TK., 1990. Impact of individual's size on density of the snail pest Achatina fulica Bowdich (Gastropoda: Achatinidae). Bollettino-Malacologico, vol. 25, no. 9-12, p. 301-306.

RAUTH, SK. and BARKER, GM., 2002. Achatina fulica Bowdich and other achatinidae as a pests in tropicultural agriculture. Molluscs as Crop Pest. New Zealand: Ed. By Landscare Research Hamilton. 472 p.

RICKER, W. 1975. Computation and interpretation of biological statistics fish populations. Journal of the Fisheries Research Board of Canada, vol. 191, p. 382.

SHAH, NK., 1992. Menagement of the Giant African Snail. Indian Farming, vol. 21, no. 5, p. 41.

SIMBERLOFF, D., 1995. Why introduced species appear to devaste islands more the mailand areas ? Pacific Science, vol. 49 , no. 1 , p. 87-97.

SMIT, H., BIJ DE VAATE, A. and FIOOLE, A., 1992. Shell growth of the zebra mussel (Dreissena polymorpha (Pallas)) in relation to selected physiochemical parameters in the Lower Rhine and some associated lakes. Archiv fur Hydrobiologie, vol. 124 , no. 3 , p. 257-280.
STATSOFT, Inc., 2003. Statistica (data analysis software system). Version 6. Available from: $<$ http://www.statsoft.com $>$.

STERGIOU, KI., 1993. Abundance-depth relationship, condition factor and adaptive value of zooplanktophagy for red bandfish, Cepola macrophtalma. Journal of Fish Biology, vol. 42 , no. 5 , p. $645-660$.

SUZUKI, H. and YASUDA, KT., 1983. Studies on Ecology and control of the giant African Snail, Achatina fulica Bowdich, in Okinawa Islands. Bulletin of the Okinawa Agricultural Experiment Station, vol. 8, p. 43-50.

TAKEDA, N. and OSAKI, T., 1986. Introduction of locomotor behaviuor in giant African Snail Achatina fulica. Comparative Biochemistry and Physiology, vol. 83, no. 1, p. 77-82.

TAKEUCHI, K., KOYANO, S. and NUMAZAWA, K., 1991. Occurrence of the Giant African Snail in Ogasawara Islands, Japan. Micronesica, no. 3, p. 109-116.

TOMIYAMA, K., 1992. Homing Behaviour of the giant African snail, Achatina fulica Fèrrusac (Gastopoda: Pulmonata). Journal of Ethology, vol. 10, no. 2, p. 139-147.

1993. Growth and maturation patterns of Giant African Snail, Achatina fulica (Ferrusàc) ( Stylommatophora: Achatinidae) in Ogasawara Islands. Venus, vol. 52, p. 87-100.

1994. Courtship behaviour of the giant African snail, Achatina fulica Fèrrusac (Stylommatophora: Achatinidae) in the field. Journal of Molluscan Studies, vol. 60, no. 1, p. 47-54.

WALZ, N., 1978. The energy balance of the freshwater mussel Dreissena polymorpha Pallas in laboratory experiments and in Lake Constance IV. Growth in Lake Constance. Archiv für Hydrobiologie, vol. 55, suppl., p. 142-156.

WEATHERLEY, AH., 1972. Growth and Ecology of Fish Populations. London: Academic Press. 293 p.

WEATHERLEY, AH. and GILL, HS., 1987. The Biology of Fish Growth. London: Academic Press. 443 p.

VINCI, GK., UNNITHAN, VK. and SUGUNAN, VV., 1998. Farming of the Giant African Snail, Achatina fulica. India: Central Inland Capture Fisheries Research Institute. no. 56, p. 1-24. 